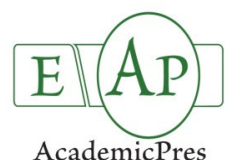

AcademicPres

\title{
Seasonal Variations in Total Antioxidant Capacity and Total Phenolics Content of Leaves of Phyllostachys Taxa Using Different Extraction Methods
}

\author{
András NEMÉNYI ${ }^{1 *}$, Éva STEFANOVITSNÉ-BÁNYAI ${ }^{2}$, Szonja Szimóna BURJÁN ${ }^{1}$, \\ Zoltán PÉK ${ }^{1}$, Attila HEGEDÜS ${ }^{3}$, Csaba GYURICZA ${ }^{4}$, Lajos HELYES ${ }^{1}$ \\ ${ }^{1}$ Szent István University, Faculty of Agricultural and Environmental Sciences, Institute of Horticulture, Páter K. u. 1., Gödöllö, 2100 Hungary; \\ nemenyi.andras@mkk.szie.hu (*orrespondingauthor) \\ ${ }^{2}$ Corvinus University of Budapest, Faculty of Food Science, Department of Applied Chemistry, Villányi üt 64-70., Budapest, 1118 Hungary \\ ${ }^{3}$ Corvinus University of Budapest, Faculty of Horticultural Science, Department of Genetics and Plant Breeding, Villányi út 64-70., Budapest, 1118 Hungary \\ ${ }^{4}$ Szent István University, Faculty of Agricultural and Environmental Sciences, Institute of Plant Production, Páter K. u. 1., Gödöllo", 2100 Hungary
}

\begin{abstract}
Changes in total phenolic content (TP) and total antioxidant capacity (AC) during the vegetation period (April-November) were analysed in Phyllostachys aureosulcata f. aureocaulis (PAA), P. flexuosa (PF), P. humilis (PH), P. sulphurea var. sulphurea (PSS). Different extraction methods were compared: infusion or decoction with water or aqueous methanol. The highest significant value for TP was measured in the case of infusion at $90^{\circ} \mathrm{C}$ for $5 \mathrm{~min}$, which lead to the highest value for AC. During the vegetation period the highest values of TP were measured in April and May in the case of $P A A(409.5 ; 314.9$ and $258.7 ; 119.0 \mu \mathrm{g} \mathrm{GA} / \mathrm{ml}) \mathrm{and} P H$ (388.4; 411.6 and 252.9; $253.3 \mu \mathrm{g} \mathrm{GA} / \mathrm{ml}$ ). There was a clear trend in the changes of TP, with high values in April and November and a peak during August-September. Similar to TP, the highest values of AC were measured in April and May in PH(519.7;566.3 and 513.5; $510.4 \mu \mathrm{g} \mathrm{AA} / \mathrm{ml})$ and $P A A(534.5 ; 337.8$ and 394.9; $275.4 \mu \mathrm{g} \mathrm{AA} / \mathrm{ml})$. We compared the change of TP in all taxa with stress index values derived from daily maximum and minimum air temperature, cumulative precipitation plus irrigation and cumulative evapotranspiration values. A close correlation $\mathrm{R}^{2}=0.32(\mathrm{p}=0.001)$ was found between stress index values and the change in TP of all taxa. The correlation is even closer $\mathrm{R}^{2}=0.52(\mathrm{p}=0.001)$ with $P F, P H$ and $P S S$. Our results with $P A A$ can be explained by possible inter/intra-specific differences in freeze tolerance and cold-acclimation.
\end{abstract}

Keywords: bamboo, Bambusoideae, herba, Poaceae, tea

\section{Introduction}

The bamboo genus Phyllostachys originated in the warm temperate regions of SE China and has long been cultivated and has naturalized in neighbouring countries such as Korea and Japan (Ohrnberger, 2002). Phyllostachys taxa have significant importance in the agriculture of Asian countries, mainly in forestry and olericulture (Kleinhenz and Midmore, 2001), but are also used in traditional Korean herbal medicine (Kim et al., 1995) and as ornamentals (Ohrnberger, 2002). The determination of human health promoting properties and phytochemicals of horticultural crops, including the measurement of antioxidant activity or total phenolics has been one of the targets of horticultural research in the past decades (Kwon et al., 2008; Im et al., 2010). The leaves of bamboo (Herba Phyllostachys) are used in traditional Chinese and Korean medical pharmacology (Kim et al., 1995; Chen and Chen, 2004), but also other herba from other bamboo taxa are used in Korea (Park and Lim, 2009; Hwang et al., 2007; Park et al., 2007). These herba have high antioxidant properties ( $\mathrm{Hu}$ et al., 2012; You et al., 2010; Park et al., 2007) and contain flavonoids
(Kim et al., 2010), phenolic acids (Park et al., 2007), chlorogenic acid derivatives (Kweon et al., 2001), phenolic and flavone glycosides (Li et al., 2008; Park et al., 2007). Leaf extracts have been shown to have anticarcinogenic (Lin et al., 2008; Shin et al., 2003), cardioprotective (Fu et al., 2006) effects, relieve lipotoxicity (Kim et al., 1995; Panee et al., 2008; Ryou et al., 2012), protect against oxidative stressinduced glaucoma (Lee et al., 2010; Kim et al., 2013). Leaf extracts can synergistically be used in combination with other compounds in the treatment of immune/allergic diseases related to mast cells (Kim et al., 2010), treatment of leukaemia (Kim et al., 2007), in the prevention and treatment of diabetic complications (Jung et al., 2007) and autoimmunity (Kim et al., 2007). Bamboo leaves are also used as food additives (Oh and Lim, 2010), and bamboo leaf extracts also exhibit antimicrobial activity during food storage (Park and Lim, 2010). The studies of Jeong et al. (2008), In et al. (2010) and Kim et al. (2012) have evaluated the nutritional components and antioxidant activities of Sasa borealis, maengjong-juk (Phyllostachys pubescens) and ojuk (Phyllostachys nigra) leaf water extracts prepared by 
traditional tea manufacturing processes. Therefore, the aim of the present study was to investigate the seasonal variations in antioxidant activity and total phenolic content of different Phyllostachys bamboo taxa leaves using different extraction methods.

\section{Materials and methods}

\section{Plant material and sample preparation}

For the comparison of different extraction methods, a sample comprised of 30 leaves that were randomly collected from a similar exposure and position within the canopy of Phyllostachys flexuosa, on the $30^{\text {th }}$ of November 2010. The bamboos are growing in the Botanical Garden of Eötvös Lóránd University (BG ELTE), Budapest, Hungary ( $47^{\circ} 29^{\prime \prime} \mathrm{N}$ latitude, $19^{\circ} 05^{\prime} 02^{\prime \prime} \mathrm{E}$ longitude and $108 \mathrm{~m}$ altitude). Four repetitive samples were collected.

For the examination of seasonal effect, 30 leaves per each sample from a similar exposure and position within the canopy were randomly collected on the last day of each month, from April to November 2011, from the following Phyllostachys taxa: $P$. aureosulcata f. aureocaulis, P. flexuosa, $P$. humilis, $P$. sulphurea var. sulphurea. Four repetitive samples were collected each month while winter sampling (from December to March) was neglected to avoid the effect of unpredictable leaf tissue freeze damage.

\section{Measurement of environmental parameters and irrigation}

Air temperature $\left({ }^{\circ} \mathrm{C}\right)$ and precipitation $(\mathrm{mm})$ were recorded during the experiment (Fig. 1). Air temperature was measured six times per hour by a meteorological instrument. Plants were irrigated by overhead sprinklers between April 1 and October 10 every 14 days with $40 \mathrm{~mm}$ of water. Potential evapotranspiration $\left(\mathrm{ET}_{0}\right)$ was calculated from that used for other vegetable crops (Helyes and Varga, 1994; Helyes et al., 2013); the amount of daily water demand was calculated based on the daily average

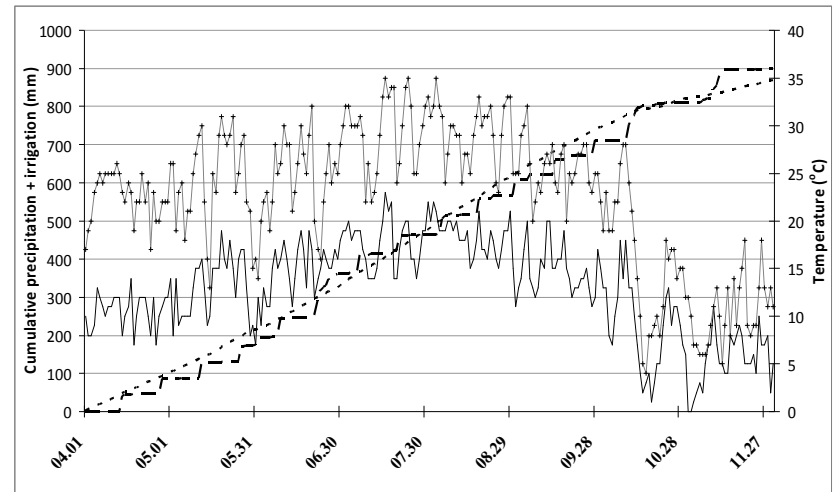

Fig. 1. Change of daily minimum, maximum air temperature $\left({ }^{\circ} \mathrm{C}\right)$, cumulative precipitation plus irrigation $(\mathrm{mm})$ and cumulative potential evapotranspiration $(\mathrm{mm})$ during the vegetation period (April-November). Grey line (+), black line, dotted line, dashed line represents maximum temperature, minimum temperature, cumulative potential evapotranspiration, cumulative precipitation plus irrigation respectively. temperature (in ${ }^{\circ} \mathrm{C}$ ) divided by five and was expressed in millimetres:

$$
I_{d}=\left(\frac{T_{\min }+T_{\max }}{2}\right) / 5
$$

Stress index (SI) was calculated for each sampling date (month) from monthly cumulative values of daily minimum air temperature Tmin $<=5^{\circ} \mathrm{C}(\mathrm{SI}$ value $5 / 0)+$ daily maximum air temperature $\operatorname{Tmax}<=5^{\circ} \mathrm{C}$ (SI value $5 / 0)+$ daily average air temperature Tave $<=5^{\circ} \mathrm{C}$ (SI value $5 / 0)+$ cumulative precipitation plus irrigation < cumulative potential evapotranspiration (SI value 1/0).

\section{Preparation of Phyllostachysleaf extracts}

To compare the different extraction methods extracts were prepared from $65^{\circ} \mathrm{C}$ air dried leaves of Phyllostachys flexuosa. Leaves were cut into small pieces, and $1 \mathrm{~g}$ of dried leaves were infused or decocted with $50 \mathrm{ml}$ water $(80,90$, or $100^{\circ} \mathrm{C} ; 5,10,20 \mathrm{~min}$ or $24 \mathrm{~h}$ or with aqueous methanol $\left(25^{\circ} \mathrm{C}\right.$; water/ methanol 80/ 20, v/v $72 \mathrm{~h}$ ). For the investigation of the effect of seasonal variation, $65^{\circ} \mathrm{C}$ air dried leaves of the different Phyllostachys taxa were also cut into small pieces, and $1 \mathrm{~g}$ of dried leaves were infused with $50 \mathrm{ml}$ water $\left(90^{\circ} \mathrm{C}, 5 \mathrm{~min}\right.$ or $\left.24 \mathrm{~h}\right)$ or with aqueous methanol $\left(25^{\circ} \mathrm{C}\right.$; water/ methanol $80 / 20$, v/v $\left.72 \mathrm{~h}\right)$. The methanolic and aqueous extracts were stored at room temperature for $24 \mathrm{~h}$. After centrifugation $(13,000 \mathrm{rpm}, 10$ min) the supernatants were stored at $-20{ }^{\circ} \mathrm{C}$ until the analyses.

\section{Determination of total phenolics content}

The total amount of soluble phenols (TP) was determined using Folin-Ciocalteu reagent according to the method of Singleton and Rossi (1970) and determined spectrophotometrically at $760 \mathrm{~nm}$. The content of soluble phenols was calculated from a standard curve obtained by different concentrations of gallic acid (GA) and given in $\mu \mathrm{g}$ $\mathrm{GA} / \mathrm{ml}$.

\section{Determination of total antioxidant capacity by FRAP assay}

The total antioxidant capacity (AC) related to ascorbic acid was determined spectrophotometrically using the FRAP (Ferric Reducing Antioxidant Power) method according to Benzie and Strain (1996). It is based on the reduction of the $\mathrm{Fe}^{3+}$-TPTZ complex to the ferrous form at low $\mathrm{pH}$. This reduction was monitored by measuring the absorption change at $593 \mathrm{~nm}$. Results were expressed as $\mu \mathrm{g}$ equivalents of ascorbic acid (AA).

\section{Statistical analysis}

Results were expressed as the average plus/minus standard deviations. The data were analysed by two-factor analysis of variance (ANOVA) with repetitions and the means separated using the LSD test at $\mathrm{p}=0.05$. Regression analysis was performed using Statistica 9 software. 
45

\section{Results and discussion}

Effect of different extraction methods on total phenolic content and antioxidant capacity in Phyllostachys flexuosa

Fig. 2 shows that the highest TP values were obtained by aqueous infusion, compared to decoction or methanolic extraction. The highest significant value of $492.3 \pm 12.7 \mu \mathrm{g}$ $\mathrm{GA} / \mathrm{ml}$ for TP was measured in the case of infusion at 90 ${ }^{\circ} \mathrm{C}$ for 5 min which lead similarly the highest measured value $(539.2 \pm 10.8 \mu \mathrm{g} \mathrm{AA} / \mathrm{ml})$ in the case of $\mathrm{AC}$, but this latter was not significantly the highest compared to infusion at $80{ }^{\circ} \mathrm{C}$ for $5 \mathrm{~min}(531.4 \pm 19.5 \mu \mathrm{g} \mathrm{AA} / \mathrm{ml})$. The second and third highest (14 and $21 \%$ lower) $\mathrm{TP}$ values were measured in the case of infusion at $90^{\circ} \mathrm{C}$ for 10 and $20 \mathrm{~min}$ $(421.3 \pm 8.4$ and $391.9 \pm 5.6 \mu \mathrm{g} \mathrm{GA} / \mathrm{ml})$ respectively, but the latter was not significantly higher than infusion at $80{ }^{\circ} \mathrm{C}$ for $20 \mathrm{~min}(365.6 \pm 25.7 \mu \mathrm{g} \mathrm{GA} / \mathrm{ml})$. TP value of infusion at 80 ${ }^{\circ} \mathrm{C}$ for $20 \mathrm{~min}(365.6 \pm 25.7 \mu \mathrm{g} \mathrm{GA} / \mathrm{ml})$ was not significantly lower than TP value of decoction at $20 \mathrm{~min}(363.4 \pm 6.7 \mu \mathrm{g}$ $\mathrm{GA} / \mathrm{ml})$. In the case of $\mathrm{AC}$ there was no significant difference between the second, third and fourth highest measured values $(531.3 \pm 19.3 ; 511.9 \pm 14.6$; and $508.6 \pm 11.7$ $\mu \mathrm{g} \mathrm{AA} / \mathrm{ml}$ ) of infusion at $80{ }^{\circ} \mathrm{C}$ for 5 and $20 \mathrm{~min}$ and at 90 ${ }^{\circ} \mathrm{C}$ for 10 min respectively. AC values of infusion at $80{ }^{\circ} \mathrm{C}$ for $10 \mathrm{~min}$ and at $90{ }^{\circ} \mathrm{C}$ for $20 \mathrm{~min}(472.8 \pm 9.2$ and $466.4 \pm 24.6 \mu \mathrm{g} \mathrm{AA} / \mathrm{ml}$ ) were significantly lower (by $7-12 \%$ ) than the above extraction methods but were not significantly different compared to each other. Methanolic extraction for $72 \mathrm{~h}$ gave similarly high $\mathrm{AC}$ values $(382.3 \pm 11.6 \mu \mathrm{g} \mathrm{AA} / \mathrm{ml})$ compared to decoction for $20 \mathrm{~min}$ $(381.7 \pm 19.4 \mu \mathrm{g} \mathrm{AA} / \mathrm{ml})$ but these values were not significantly different from each other. AC values of methanolic extraction for $72 \mathrm{~h}(382.3 \pm 11.6 \mu \mathrm{g} \mathrm{AA} / \mathrm{ml})$ and decoction for $20 \mathrm{~min}(381.7 \pm 19.4 \mu \mathrm{gAA} / \mathrm{ml})$ were $29 \%$ lower than infusion at $90{ }^{\circ} \mathrm{C}$ for $5 \mathrm{~min}(539.2 \pm 10.8 \mu \mathrm{g}$ $\mathrm{AA} / \mathrm{ml})$. The method of extraction and the used solvent had a significant effect on extraction yield of polyphenols

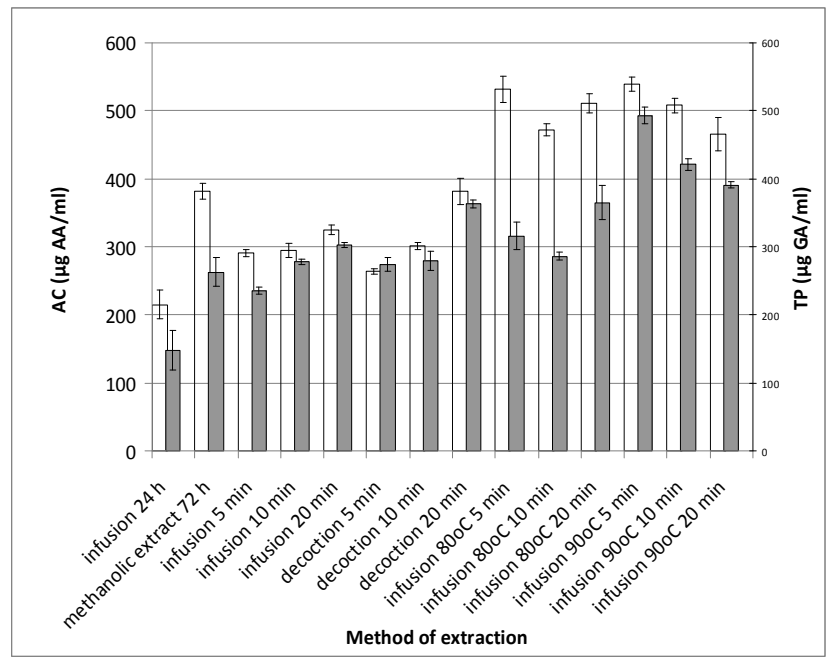

Fig. 2. Total phenolics content (TP) ( $\mu \mathrm{g} \mathrm{GA} / \mathrm{ml})$ and antioxidant capacity (AC) ( $\mu \mathrm{g} \mathrm{AA} / \mathrm{ml})$ of leaf extracts of Phyllostachys flexuosa using different extraction methods and times $(n=4, \pm S D)$. White and grey columns refer to antioxidant capacity and total phenolic content, respectively. and on antioxidant activity in teas, but results vary depending on which solvent and method produces the highest levels. In Camellia sinensis tea, Wang and Helliwell (2001), found aqueous ethanol as the best solvent, Turkmen et al. (2006) suggested N,N-dimethylformamide, while Khokhar and Magnusdottír (2002) reported water to be the best solvent of cathecins. Park and Lim (2009) have found that in the leaves of bamboo Sasa borealis the total polyphenol contents of the $70 \%$ ethanol and the water crude extracts were not significantly different, while in the $70 \%$ ethanolic extract the total flavonoid contents were significantly higher than in water crude extracts. Our extraction results with aqueous infusion were similar to those of Perva-Uzunalic et al. (2006) who have found the highest extraction efficiency of Camellia sinensis tea cathecins with aqueous infusion at $80^{\circ} \mathrm{C}$ for $20 \mathrm{~min}(97 \%)$ and at $95^{\circ} \mathrm{C}$ for $10 \mathrm{~min}(90 \%)$. Our results were also comparable to those of Jeong et al. (2008) with Sasa borealis leaf tea, with the specification that they found the highest PT in $80 \%$ methanol extract, and also with those of Kim et al. (2012), although freeze-drying in their case can account for the much higher values of TP found in $P$. nigra infused with $80{ }^{\circ} \mathrm{C}$ water for $10 \mathrm{~min}$. The TP values of aqueous extractions in this study were similar to those of In et al. (2010) in the case of maengjong-juk (Phyllostachys pubescens) leaf tea.

\section{Changes in total phenolic content and antioxidant capacity throughout the vegetation period in different Phyllostachys taxa}

\section{Changes in total phenolics content}

Tab. 1 shows the results of all three extraction methods (infusion $90^{\circ} \mathrm{C}, 5 \mathrm{~min}$ or $24 \mathrm{~h}$ or aqueous methanol $72 \mathrm{~h}$ ). The highest values were obtained in the case of infusion at $90{ }^{\circ} \mathrm{C}$, for $5 \mathrm{~min}$ or $24 \mathrm{~h}$. Only in May, August and September the values were slightly higher (11-14\% higher on average) with infusion at $90{ }^{\circ} \mathrm{C}$ for $24 \mathrm{~h}$ compared to infusion at $90{ }^{\circ} \mathrm{C}$ for $5 \mathrm{~min}$. The lowest (33-39\% lower on average) values were measured for aqueous methanol for 72 h. During the course of the vegetation period the highest values of TP were measured in April and May in the case of $P$. aureosulcata f. aureocaulis and $P$. bumilis with infusion at $90{ }^{\circ} \mathrm{C}$ for $24 \mathrm{~h}$ or with aqueous methanol for $72 \mathrm{~h}$, and the difference was not significant. Only in the case of infusion at $90{ }^{\circ} \mathrm{C}$ for $5 \mathrm{~min}$ were the TP values of $P$. humilis significantly higher than $P$. aureosulcata $f$. aureocaulis during April and May. Throughout the vegetation period the highest TP values were more or less consistently measured in these two taxa. There was no significant change in TP values of $P$. flexuosa with infusion at $90{ }^{\circ} \mathrm{C}$ for $5 \mathrm{~min}$ or with aqueous methanol for $72 \mathrm{~h}$ between April and August, while values of infusion at $90{ }^{\circ} \mathrm{C}$ for $24 \mathrm{~h}$ showed significant slight decline (by 13\%) in this species until August. Changes in TP values of $P$. flexuosa, $P$. humilis and $P$. sulphurea var. sulphurea from September to November were significantly different and showed the same tendency with the three extraction methods. P. flexuosa had the lowest values during most months, with the significantly lowest value in October 
with aqueous methanolic extraction for $72 \mathrm{~h}$, but the difference in other months compared especially to $P$. sulphurea var. sulphurea was not always significant. If we compared the changes in all taxa shown in Tab. 1, there was a clear trend in the changes of TP during the vegetation period, with high values in April and November, which is consistent with the findings of Zhang et al. (2002) who have found the highest total flavonoid level in Phyllostachys nigra leaves between November and April and of Ni et al. (2012) who have reported that total phenolics and total flavonoids in leaves of bamboo Sasa argenteostriatus were the highest from November to March. In addition, the same tendency was measured in leaves of bamboos Indocalamus herklotsii, I. decorus and I. latifolius by $\mathrm{Su}$ et al. (2011) and in Phyllostachys heterocycla, Pleioblastus amaru, Dendrocalamus oldhami and Acidosasa edulis by Lü et al. (2011). TP values declined during May, June and July and the change was significant for most extraction methods, months and taxa except for $P$. flexuosa, as described above. This decline is also reflected in the report of Zhang et al. (2002) and Ni et al. (2012). Our results clearly show a peak in August and September which has not been reported in the literature before, with an abrupt drop and low values in October. $P$. aureosulcata $f$. aureocaulis was the only taxon which had exactly the opposite tendency in October compared to the other taxa, with the highest significantly $\mathrm{TP}$ values $(292.6 \pm 9.2 ; 386.0 \pm 13.2 ; 207.9 \pm 2.8 \mu \mathrm{g} \mathrm{GA} / \mathrm{ml})$ with all three extractions (infusion $90^{\circ} \mathrm{C}, 5 \mathrm{~min}$ or $24 \mathrm{~h}$ or aqueous methanol $72 \mathrm{~h}$. This indicated a putative effect of the environmental factors on total phenolic contents of bamboo leaves, which required further analyses.

Tab. 1. Changes in total phenolics (TP) content $(\mu \mathrm{g} \mathrm{GA} / \mathrm{ml}$ ) and antioxidant (AC) capacity ( $\mu \mathrm{g} \mathrm{AA} / \mathrm{ml})$ using different extraction methods (M-methanol; A-aqueous infusion; 90 - infusion at $90{ }^{\circ} \mathrm{C}$ for $5 \mathrm{~min}$ ) Phyllostachys taxa between April and November. PAA-Phyllostachys aureosulcata f. aureocaulis, PF-P. flexuosa, PH-P. humilis,PSS-P. sulphurea var. sulphurea

\begin{tabular}{|c|c|c|c|c|c|c|c|}
\hline Month & Taxon & TPM & $\mathrm{ACM}$ & TPA & ACA & TP90 & AC90 \\
\hline \multirow[t]{4}{*}{ April } & PAA & $258.7 \pm 8.0$ & $534.5 \pm 9.2$ & $409.5 \pm 12.0$ & $334.9 \pm 4.0$ & $266.1 \pm 12,1$ & $337.8 \pm 12.8$ \\
\hline & PF & $183.9 \pm 4.8$ & $334.8 \pm 3.2$ & $252.9 \pm 2.0$ & $261.3 \pm 2.5$ & $257.9 \pm 4.4$ & $339.2 \pm 7.2$ \\
\hline & $\mathrm{PH}$ & $252.9 \pm 8.0$ & $519.7 \pm 8.4$ & $388.4 \pm 8.1$ & $339.5 \pm 4.1$ & $391.3 \pm 4.3$ & $513.5 \pm 13.2$ \\
\hline & PSS & $178.1 \pm 12.1$ & $302.3 \pm 14.0$ & $259.1 \pm 20.4$ & $223.8 \pm 10.8$ & $244.6 \pm 2.0$ & $329.2 \pm 25.2$ \\
\hline \multirow[t]{4}{*}{ May } & PAA & $119.0 \pm 8.0$ & $394.9 \pm 11.2$ & $314.9 \pm 10.5$ & $225.3 \pm 11.6$ & $214.0 \pm 22.7$ & $275.4 \pm 13.6$ \\
\hline & $\mathrm{PF}$ & $171.1 \pm 16.2$ & $328.7 \pm 6.8$ & $279.8 \pm 8.8$ & $220.7 \pm 17.6$ & $232.2 \pm 9.2$ & $302.0 \pm 20.4$ \\
\hline & $\mathrm{PH}$ & $253.3 \pm 4.0$ & $566.3 \pm 26.4$ & $411.6 \pm 2.1$ & $339.5 \pm 2.0$ & $395.0 \pm 14.7$ & $510.4 \pm 15.2$ \\
\hline & PSS & $154.1 \pm 8.7$ & $280.6 \pm 4.0$ & $241.7 \pm 8.0$ & $191.5 \pm 6.7$ & $195.0 \pm 8.8$ & $259.9 \pm 7.6$ \\
\hline \multirow[t]{4}{*}{ June } & PAA & $112.7 \pm 4.1$ & $399.5 \pm 8.3$ & $278.1 \pm 1.2$ & $193.6 \pm 7.2$ & $240.1 \pm 16.4$ & $355.5 \pm 4.8$ \\
\hline & PF & $148.8 \pm 28.0$ & $339.4 \pm 4.0$ & $262.4 \pm 4.7$ & $157.5 \pm 23.6$ & $240.1 \pm 18.2$ & $346.4 \pm 19.2$ \\
\hline & $\mathrm{PH}$ & $205.4 \pm 4.3$ & $442.8 \pm 30.0$ & $334.7 \pm 24$ & $244.1 \pm 18.4$ & $295.0 \pm 28.0$ & $408.5 \pm 22.7$ \\
\hline & PSS & $109.5 \pm 14.0$ & $175.1 \pm 19.2$ & $178.1 \pm 17.6$ & $69.5 \pm 6.8$ & $190.5 \pm 22.1$ & $264.5 \pm 18.0$ \\
\hline \multirow[t]{4}{*}{ July } & PAA & $144.6 \pm 2.5$ & $344.6 \pm 3.6$ & $251.2 \pm 4.0$ & $143.1 \pm 2.0$ & $226.4 \pm 21.6$ & $320.9 \pm 21.2$ \\
\hline & $\mathrm{PF}$ & $132.2 \pm 6.1$ & $260.9 \pm 4.0$ & $212.4 \pm 4.9$ & $135.7 \pm 6.4$ & $225.2 \pm 11.2$ & $324.6 \pm 16.0$ \\
\hline & $\mathrm{PH}$ & $139.3 \pm 16.2$ & $291.9 \pm 9.6$ & $238.8 \pm 8.1$ & $124.1 \pm 15.2$ & $191.3 \pm 15.2$ & $266.8 \pm 7.2$ \\
\hline & PSS & $90.5 \pm 6.0$ & $119.0 \pm 11.2$ & $126.4 \pm 8.0$ & $31.9 \pm 6.8$ & $145.5 \pm 22.6$ & $209.5 \pm 14.1$ \\
\hline \multirow[t]{4}{*}{ August } & PAA & $178.5 \pm 14.3$ & $383.0 \pm 4.0$ & $290.1 \pm 8.2$ & $187.7 \pm 8$ & $184.3 \pm 12.3$ & $331.8 \pm 1.2$ \\
\hline & PF & $153.3 \pm 18.4$ & $329.9 \pm 6.8$ & $255.8 \pm 12.3$ & $151.6 \pm 8.0$ & $268.6 \pm 20.0$ & $373.5 \pm 20.0$ \\
\hline & $\mathrm{PH}$ & $181.0 \pm 8.0$ & $430.8 \pm 12.4$ & $372.7 \pm 28.7$ & $190.9 \pm 6.4$ & $177.3 \pm 19.6$ & $394.2 \pm 3.2$ \\
\hline & PSS & $190.1 \pm 2.7$ & $272.0 \pm 2.0$ & $256.2 \pm 18.0$ & $163.2 \pm 6.8$ & $272.3 \pm 3.2$ & $446.3 \pm 15.6$ \\
\hline \multirow[t]{4}{*}{ September } & PAA & $153.7 \pm 4.8$ & $365.8 \pm 7.6$ & $283.9 \pm 6.4$ & $131.2 \pm 4.8$ & $202.5 \pm 16.0$ & $376.7 \pm 8.8$ \\
\hline & $\mathrm{PF}$ & $185.1 \pm 4.8$ & $386 \pm 16.0$ & $311.2 \pm 8.1$ & $175.0 \pm 7.2$ & $254.1 \pm 4.1$ & $406.7 \pm 18.4$ \\
\hline & $\mathrm{PH}$ & $196.7 \pm 24.1$ & $437.6 \pm 2.8$ & $335.5 \pm 14.7$ & $194.2 \pm 22.4$ & $268.2 \pm 28.4$ & $378.1 \pm 7.2$ \\
\hline & PSS & $174.8 \pm 2.0$ & $320.7 \pm 12.4$ & $281.0 \pm 5.2$ & $141.0 \pm 1.6$ & $294.6 \pm 24.2$ & $400.2 \pm 11.2$ \\
\hline \multirow[t]{4}{*}{ October } & PAA & $207.9 \pm 2.8$ & $438.0 \pm 16.8$ & $386.0 \pm 13.2$ & $208.7 \pm 1.2$ & $292.6 \pm 9.2$ & $350.1 \pm 7.2$ \\
\hline & $\mathrm{PF}$ & $56.6 \pm 16.2$ & $142.8 \pm 15.6$ & $93.8 \pm 11.2$ & $22.5 \pm 15.2$ & $81.4 \pm 4.0$ & $163.2 \pm 7.2$ \\
\hline & $\mathrm{PH}$ & $155.8 \pm 3.6$ & $191.8 \pm 8.0$ & $212.4 \pm 14.4$ & $133.3 \pm 6.0$ & $249.2 \pm 23.2$ & $367.0 \pm 20.4$ \\
\hline & PSS & $73.6 \pm 8.0$ & $139.4 \pm 19.2$ & $126.9 \pm 18.0$ & $33.4 \pm 4.8$ & $103.7 \pm 2.8$ & $149.4 \pm 11.2$ \\
\hline \multirow[t]{4}{*}{ November } & PAA & $180.2 \pm 16.8$ & $314.9 \pm 4.8$ & $270.7 \pm 17.6$ & $190.6 \pm 18.0$ & $235.1 \pm 15.6$ & $329.8 \pm 2.0$ \\
\hline & $\mathrm{PF}$ & $252.1 \pm 16.7$ & $303.1 \pm 16.0$ & $255.8 \pm 14.0$ & $232.0 \pm 27.6$ & $245.9 \pm 6.0$ & $363.2 \pm 27.6$ \\
\hline & $\mathrm{PH}$ & $190.1 \pm 4.0$ & $413.3 \pm 5.6$ & $311.6 \pm 15.2$ & $185.9 \pm 2.0$ & $318.6 \pm 8.1$ & $420.2 \pm 22.4$ \\
\hline & PSS & $154.1 \pm 6.8$ & $249.6 \pm 8.4$ & $205.0 \pm 3.2$ & $134.8 \pm 2.4$ & $232.2 \pm 14.4$ & $298.3 \pm 21.6$ \\
\hline Month & & $*$ & $* * *$ & $*$ & $* * *$ & NS & NS \\
\hline Genotype & & * & $* * *$ & $* * *$ & $* * *$ & $*$ & $*$ \\
\hline Month ${ }^{\mathrm{x}}$ Genotype & & * & $* * *$ & $* *$ & *** & $*$ & $*$ \\
\hline
\end{tabular}




\section{Changes in total antioxidant capacity}

Results for $\mathrm{AC}$ in the case of all three extraction methods (infusion $90{ }^{\circ} \mathrm{C}, 5 \mathrm{~min}$ or $24 \mathrm{~h}$ or aqueous methanol $72 \mathrm{~h}$ ) are shown in Tab. 1 . The highest AC values were obtained in the case of infusion at $90^{\circ} \mathrm{C}$, for $5 \mathrm{~min}$. Somewhat lower (8-17\% lower on average) values were measured with aqueous methanol for $72 \mathrm{~h}$. Only in April and May, values were similar or slightly higher $(12 \%$ higher on average) with aqueous methanolic extraction for $72 \mathrm{~h}$ compared to infusion at $90{ }^{\circ} \mathrm{C}$ for $5 \mathrm{~min}$. The lowest (31$59 \%$ lower on average) values were measured for infusion at $90{ }^{\circ} \mathrm{C}$ for $24 \mathrm{~h}$. Similar to the results described for TP during the examined period the highest values of $\mathrm{AC}$ were measured in April and May also in $P$. humilis and $P$. aureosulcata $f$. aureocaulis but this time in the case of aqueous methanolic extraction for $72 \mathrm{~h}$ and infusion at 90 ${ }^{\circ} \mathrm{C}$ for $5 \mathrm{~min}$, but the difference was not always significant. Only in the case of infusion at $90^{\circ} \mathrm{C}$ for $5 \mathrm{~min}$ were the AC values of $P$. bumilis significantly higher than those of $P$. aureosulcata $f$. aureocaulis during both months of April and May. During the course of the examined period similar to the results of TP the highest $\mathrm{AC}$ values were more or less consistently measured in these two taxa. As the results of TP, there was no significant change in AC values of $P$. flexuosa with aqueous methanol for $72 \mathrm{~h}$ or with infusion at $90{ }^{\circ} \mathrm{C}$ for $5 \mathrm{~min}$ or between April and August, while values of infusion at $90{ }^{\circ} \mathrm{C}$ for $24 \mathrm{~h}$ showed a significant decline (by $50 \%$ ) in this species until August. From September to November changes in AC values of $P$. flexuosa, $P$. humilis and $P$. sulphurea var. sulphurea were significantly different and showed the same tendency with the three extraction methods, as in the case of TP. P. flexuosa and P. sulphureaf. sulphurea had the lowest values during most months, with the lowest value for P. flexuosa in October with infusion at $90{ }^{\circ} \mathrm{C}$ for $24 \mathrm{~h}$, but the difference was not significant compared to $P$. sulphurea var. sulphurea. When changes in all taxa were compared (see Tab. 1), there was a clear trend in the changes of $\mathrm{AC}$ during the vegetation period, with high values in April and November, which is similar to the findings of Zhang et al. (2002) who have found the highest antioxidant activity in Phyllostachys nigra leaves, between autumn and spring, with the strongest measured activity in February. The results of Ni et al. (2012) also showed that the highest antioxidant activity in bamboo Sasa argenteostriatus leaves occurred in December and remained generally high from October to April. AC values declined during May, June and July and the change was significant for most months, extraction methods and all taxa except for $P$. flexuosa, as described above. This decline is also reflected in the report of Zhang et al. (2002) and Ni et al. (2012). Our results clearly showed a peak in August and September which has not been reported in the literature before, then a steep decline and low values in October. P. aureosulcata f. aureocaulis was the only taxon which had exactly the opposite tendency in October compared to the other taxa, with significantly AC higher values with infusion at $90{ }^{\circ} \mathrm{C}$ for $24 \mathrm{~h}$ or aqueous methanol for $72 \mathrm{~h}$. Since both $\mathrm{Hu}$ et al. (2012) and $\mathrm{Ni}$ et al. (2012) have found a positive correlation between bamboo total phenolics and antioxidant activity our results were also in agreement with those of Su et al. (2011) and Lü et al. (2011).

\section{Correlation between environmental parameters and total phenolic content}

A late summer peak in TP values has not been reported in the literature before and since Phyllostachys is neither native nor naturalized in Hungary, we examined the possible environmental cause of this phenomenon. Environmental parameters including daily maximum and minimum temperature $\left({ }^{\circ} \mathrm{C}\right)$, cumulative precipitation plus irrigation (CPI) and cumulative potential evapotranspiration (CE) values, for the examined April to November period, are shown on Fig. 1. The temperature range was more or less the same till early May, and remained with larger variations till the end of May. From the beginning of June both daily minimum (were above +10 ${ }^{\circ} \mathrm{C}$ ) and maximum (were above $+15^{\circ} \mathrm{C}$ ) values started to rise and levelled off between mid-July to mid-August. From mid-August temperatures started to decline and the lowest daily minimum and maximum temperatures (at or below $+5^{\circ} \mathrm{C}$ ) were recorded from mid-October. CPI values were similar or lower than the $\mathrm{CE}$ values till late June. From late June CPI values were higher than the CE values until the end of July. From early August CPI values were lower than $\mathrm{CE}$ values until mid-October. From mid-October, CPI values were similar or higher than $\mathrm{CE}$. The above changes in $\mathrm{CPI}$ compared to $\mathrm{CE}$ can be interpreted, as there was probably water surplus during the period between late June and end of July and between mid-October and end of November. Abiotic stress factors are known to induce phenylpropanoid metabolism (Dixon and Paiva, 1995) including temperature (Janda et al., 1999; Pál et al., 2013) and water stress (De Abreu and Mazzafera, 2005). To find correlation between TP and water and/or temperature stress, changes of TP in the case of all taxa and extraction methods expressed as \% of maximum value were compared, with stress index values derived from daily maximum and minimum temperature, $\mathrm{CPI}$ and $\mathrm{CE}$ values for the examined April to November period. A close correlation $\mathrm{R}^{2}$ $=0.32(p=0.001)$ was found between stress index values and the change in TP shown on Fig. 3. By comparing the change of TP in $P$. flexuosa, $P$. humilis and $P$. suphurea var. sulphurea, with stress index values the correlation is even closer $\mathrm{R}^{2}=0.52(\mathrm{p}=0.001)$. Our results were in agreement with the findings of Oh et al. (2009) who have found that low temperatures caused an increase in total phenolics content in lettuce. The same was reported for Hypericum perforatum (Zobayed et al., 2005). The effect of altitudinal variation also caused an increase in total phenolic and flavanoid contents and antioxidant activity in bamboo Indocalamus latifolius ( $\mathrm{Ni}$ et al., 2013). Our findings are especially in conjunction with those of De Abreu and Mazzafera (2005) who have found that water or low temperature stress caused an increase of phenolic contents in Hypericum brasiliense. During the cold-acclimation of plants an accumulation of secondary metabolites, including TP was reported by Cansev et al. (2012) and Pennycooke et al. (2005). Our interesting results with $P$. aureosulcata $f$. aureocaulis in which TP values immediately rose after 
exposure to low temperatures in October, while the other taxa produced high values only later in November, could be explained by the different freeze tolerance of these species, $P$. aureosulcata being the most freeze tolerant of the four taxa (Ohrnberger, 2002), and also by possible inter/intraspecific differences in responsiveness to low temperature exposure during cold-acclimation as reported for other plants (Li et al., 2002; Li et al., 2005; Guárdia et al., 2013). Previous available studies on bamboos have not attempted to find reasons for seasonal changes in TP, only defined the period of the year optimal for harvest of bamboo leaves rich in TP. Our findings suggested that climatically applicable exposure to moderate water stress and low temperatures could enhance the phytochemical content of bamboo leaves intended for harvest as herba or food additive. But further specific experiments involving temperature and or water stress with regards to phytochemical content of bamboo leaves need to be carried out to underline this.

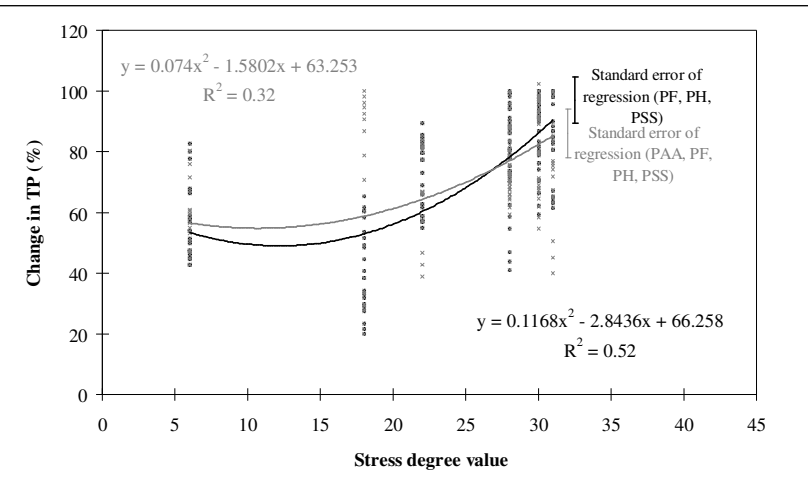

Fig. 3. Correlation between stress index and change in TP content (\%) expressed as average of all four taxa PAAPhyllostachys aureosulcata f. aureocaulis, PF-P. flexuosa, PH-P. humilis, PSS-P. sulphurea var. sulphurea or three taxa except Phyllostachys aureosulcata $f$. aureocaulis. $(\mathrm{p}=0.001)$. Black and grey dots and lines refer to (PF, PH, PSS) and (PAA, PF, PH, PSS) respectively.

\section{Conclusions}

The highest significant TP and AC values were obtained by aqueous infusion at $90{ }^{\circ} \mathrm{C}$ for $5 \mathrm{~min}$. During the vegetation period the highest values of TP and $A C$ were measured in April and May in the case of $P A A$ and $P H$. The lowest values during most months were measured in $P F$ and PSS. Changes of TP and AC during the vegetation period gave high values in April and November in all taxa. A peak in TP and AC detected in August-September has not been reported in the literature before. Compared to the other taxa $P A A$ produced exactly the opposite tendency in October, with significantly the highest TP and AC values. A close correlation was found between stress index values and the change in TP showing that water or low temperature stress caused an increase of phenolic contents. The results of $P A A$ could possibly be explained by inter/intra-specific differences during cold-acclimation in the responsiveness to low temperature exposure.

\section{Acknowledgements}

This study was funded by TÁMOP-4.2.1. B-11/2/ KMR 2011-0003 and Research Centre of Excellence 17586-4/2013/TUDPOL Szent István University and KTIA_AIK_12-1-2012-0012 project and OTKA K84290 project. Attila Hegedüs acknowledges a János Bolyai Scholarship, Hungarian Academy of Sciences.

\section{References}

Benzie IFF, Strain JJ (1996). The ferric reducing ability of plasma (FRAP) as a measure of "antioxidant power": the FRAP assay. Anal Biochem 239(1):70-76.

Cansev A, Gulen H, Celik G, Eris A (2012). Alterations in total phenolic content and antioxidant capacity in response to low temperatures in olive (Olea europea L. 'Gemlik'). Plant Arch 12(1):489-494.

Chen JK, Chen TT (2004). Chinese Medical Herbology and Pharmacology. $1^{\text {st }}$ Ed. Art of Medicine Press, City of Industry, $1267 \mathrm{p}$.

De Abreu IN, Mazzafera P (2005). Effect of water and temperature stress on the content of active constituents of Hypericum brasiliense Choisy. Plant Physiol Biochem 43(3):241-248.

Dixon RA, Paiva NL (1995). Stress-induced phenylpropanoid metabolism. The Plant Cell 7(7):1085-1097.

Fu XC, Wang MW, Li SP, Wang HL (2006). Anti-apoptic effect and the mechanism of orientin on ischaemic/reperfused myocardium. J Asian Nat Prod Res 8(3):265-272.

Guárdia M, Savé R, Diaz R, Vilanova A, Aletá N (2013). Genotype and environment: two factors related to autumn cold hardiness on Persian walnut (Juglans regia L.). Ann Forest Sci 70(8):791-800.

Helyes L, Neményi A, Pék Z, Berki M, Daood HG (2013). Effect of variety and water supply on phytochemical (phenolics and carotenoids) content and composition of processing tomato. Acta Hort 971:93-98.

Helyes L, Varga Gy (1994). Irrigation demand of tomato according to the results of three decades. Acta Hort 376:323328.

Hu C, Xu D, Chen H, Yuan K (2012). Contents of the total flavonoids and the total phenols and antioxidant activities in the leaf from different species of Phyllostachys. Adv Mat Res 343-344:1103-1108.

Hwang JH, Choi SY, Ko HC, Jang MG, Jin YJ, Kang SI, Park JG, Chung WS, Kim SJ (2007). Anti-inflammatory effect of the hot water extract from Sasa quelpaertensis leaves. Food Sci Biotechnol 16(5):728-733.

Im JS, Lee EH, Lee JN, Kim KD, Kim HY, Kim MJ (2010). Sulforaphane and total phenolics contents and antioxidant activity of radish according to genotype and cultivation location with different altitudes. Korean J Hortic Sci 28(3):335-342. 
49

In MJ, Park MK, Kim S, Chae HJ, Chae MW, Sone J, Ji H-S, Han KS, Kim DC (2010). Composition analysis and antioxidative activity of maengjong-juk (Phyllostachys pubescens) leaves tea. J Appl Biol Chem 53(2):116-119.

Janda T, Szalai G, Tari I, Páldi E (1999). Hydroponic treatment with salicylic acid decreases the effects of chilling injury in maize (Zea mays L.) plants. Planta 208(2):175-180.

Jeong CH, Choi SG, Heo HJ (2008). Analysis of nutritional components and evaluation of functional activities of Sasa borealis leaf tea. Korean J Food Sci Technol 40(5):586-592.

Jung SH, Lee JM, Lee HJ, Kim CY, Lee EH, Um BH (2007). Aldose reductase and advanced glycation endproducts inhibitory effect of Phyllostachys nigra. Biol Pharm Bull 30(8):1569-1572.

Khokhar S, Magnusdottír SGM (2002). Total phenol, catechin, and caffeine contents of teas commonly consumed in the United Kingdom. J Agr Food Chem 50(3):565-570.

Kim DS, Son EJ, Kim M, Heo YM, Nam JB, Ro JY, Woo S-S 2010. Antiallergic herbal composition from Scutellaria baicalensis and Phyllostachys edulis. Planta Med 76(7):678682.

Kim KA, Kang KD, Jo H, Lee HJ, Kim CY, Um BH, Jung SH (2013). Compound isolated from the leaves of Phyllostachys nigra protects NMDA-induced retinal degeneration. J Food Biochem 37(4):465-474.

Kim NJ, Lee SJ, Kwon CH, Hong ND (1995). Antilipoperoxidant effects of leaves of Phyllostachys bambusoides S. et Z. Korean J Pharmacognosy 26(4):368-376.

Kim SH, Kim TS, Kim SJ, Seong CN, Lee OH, Lee HJ, Yoo JC (2007). Inhibition of interleukin-12 production in mouse macrophages via suppression of nuclear factor-xB binding activity by Phyllostachys nigra var. henonis. Immunopharm Immunot 29(1):131-139.

Kim SH, Kim TS, Lee HJ, Yoo JC (2007). Enhancement of 1,25dihydroxyvitamin D3- and all-trans retinoic acid-induced differentiation of human leukemia HL-60 cells by Phyllostachys nigra var. henonis. Immunopharm Immunot 29(1):119-129.

Kim SM, Jeon JS, Kang SW, Kim WR, Lee KD, Um BH. (2012). Composition analysis and antioxidant activity of ojuk (Phyllostachys nigra Munro) leaf tea and shoot tea. J Appl Biol Chem 55(2):95-101.

Kleinhenz V. Midmore D (2001). Aspects of bamboo agronomy. Adv Agron 74:99-146.

Kweon MH, Hwang HJ, Sung HC (2001). Identification and antioxidant activity of novel chlorogenic acid derivatives from bamboo (Phyllostachys edulis). J Agr Food Chem 49(10):4646-4655.

Kwon YD, Ko EY, Hong SJ, Park SW (2008). Comparison of sulforaphane and antioxidant contents according to different parts and maturity of broccoli. Korean J Hortic Sci 26(3):344349.
Lee HJ, Kim K-A, Kang KD, Lee EH, Kim CY, Um BH, Jung SH (2010). The compound isolated from the leaves of Phyllostachys nigra protects oxidative stress-induced retinal ganglion cells death. Food Chem Toxicol 48(6):1721-1727.

Li C, Puhakainen T, Welling A, Viherá-Aarnio A, Ernstsen A, Junttila O, Heino P, Palva ET (2002). Cold acclimation in silver birch (Betula pendula). Development of freezing tolerance in different tissues and climatic ecotypes. Physiol Plantarum 116(4):478-488.

Li C, Wu N, Liu S (2005). Development of freezing tolerance in different altitudinal ecotypes of Salix paraplesia. Biol Plantarum 49(1):65-71.

Li T, Park MH, Kim MJ, Ryu BM, Kim MJ, Moon GS (2008). Tachioside, an antioxidative phenolic glycoside from bamboo species. Food Sci Biotechnol 17(6):1376-1378.

Lin Y, Collier AC, Liu W, Berry MJ, Panee J (2008). The inhibitory effect of bamboo extract on the development of 7 , 12-dimethylbenz[a]anthracene (DMBA)-induced breast cancer. Phytother Res 22(11):1440-1445.

Lü ZL, Ren ML, Quyang YL, Lin X, Zhang BL (2011). Seasonal variations of flavonoid contents in leaves of four of bamboo species. Beijing Linye Daxue Xuebao/Journal of Beijing Forestry University 33(4):81-84.

Ni Q, Wang Z, Xu G, Gao Q, Yang D, Morimatsu F, Zhang Y (2013). Altitudinal variation of antioxidant components and capability in Indocalamus latifolius (Keng) McClure leaf. J Nutr Sci Vitaminol 59(4):336-342.

Ni Q, Xu G, Wang Z, Gao Q, Wang S, Zhang Y (2012). Seasonal variations of the antioxidant composition in ground bamboo Sasa argenteastriatus leaves. Int J Mol Sci 13(2):2249-2262.

Oh H-K, Lim H-S (2010). Quality characteristics of the hamburger patties with bamboo (Sasa borealis) leaf extract with/without cooked rice. Korean J Food Sci An 30(5):833841.

Oh M-M, Carey EE, Rajashekar CB (2009). Environmental stresses induce health-promoting phytochemicals in lettuce. Plant Physiol Bioch 47(7):578-583.

Ohrnberger D (2002). Bamboos of the world: Annotated nomenclature and literature of the species and higher and lower taxa. $1^{\text {st }}$ Ed. Elsevier Science B.V., Amsterdam, 596 p.

Pál M, Gondor OK, Janda T (2013). Role of salicylic acid in acclimation to low temperature. Acta Agron Hung 61(2):161172.

Panee J, Liu W, Lin Y, Gilman C, Berry MJ (2008). A novel function of bamboo extract in relieving lipotoxicity. Phytother Res 22(5):675-680.

Park HS, Ju HL, Hyun JK, Hyun JC, Lee IS (2007). Antioxidant flavone glycosides from the leaves of Sasa borealis. Arch Pharm Res 30(2):161-166.

Park YO, Lim HS (2009). Antioxidant activities of bamboo (Sasa borealis) leaf extract according to extraction solvent. J Korean Soc Food Sci Nutr 38(12):1640-1648. 
Park YO, Lim HS (2010). Antimicrobial activity of bamboo (Sasa borealis) leaves fraction extracts against food poisoning bacteria. J Korean Soc Food Sci Nutr 39(12): 1745-1752.

Pennycooke JC, Cox S, Stushnoff C (2005). Relationship of cold acclimation, total phenolic content and antioxidant capacity with chilling tolerance in petunia (Petunia $x$ hybrida). Environ Exp Bot 53(2):225-232.

Perva-Uzunalic A, Skerget M, Knez Z, Weinreich B, Otto F, Grüner $S$ (2006). Extraction of active ingredients from green tea (Camellia sinensis): Extraction efficiency of major cathecins and caffeine. Food Chem 96(4):597-605.

Ryou SH, Kang MS, Kim KI, Kang YH, Kang JS (2012). Effects of green tea or Sasa quelpartensis bamboo leaves on plasma and liver lipids, erythrocyte $\mathrm{Na}$ efflux, and platelet aggregation in ovariectomized rats. Nutr Res Pract 6(2):106-112.

Shin DH, Kim JC, Kim SR, Oh H, Park IC, Oh KS, Chung HJ, Jang JS, Kim SH (2003). The effect of Phyllostachys nigra var henonis Strapf. leaf extract in the gamma-irradiated mice. Korean J Vet Res 43(1):49-55.

Singleton VL, Rossi JA (1965). Colometry of total phenolics with phosphomolibdic-phosphotungstic acid reagents. Am J Enol Viticult 161(3):144-158.
Su CH, Liu GH, Wang FS, Ding YL, Xue JH (2011). Seasonal changes of Indocalamus leaf active ingredients contents. Chinese J Appl Ecol 22(9):2471-2476.

Turkmen N, Sari F, Velioglu YS (2006). Effects of extraction solvents on concentration and antioxidant activity of black and black mate tea polyphenols determined by ferrous tartrate and Folin-Ciocalteu methods. Food Chem 99(4):835-841.

Wang H, Helliwell K (2001). Determination of flavonols in green and black tea leaves and green tea infusions by highperformance liquid chromatography. Food Res Int 34(23):223-227.

You Y, Kim K, Yoon HG, Lee J, Chun J, Shin DH, Park J, Jun W (2010). Chronic effect of ferulic acid from Pseudosasa japonica leaves on enhancing exercise activity in mice. Phytother Res 24(10):1508-1513.

Zhang Y, Wu XQ, Yu ZY (2002). Studies on seasonal variation of flavonoids and lactones in bamboo leaves. Linchan Huaxue $\mathrm{Yu}$ Gongye/Chemistry and Industry of Forest Products 22(2):65-69.

Zobayed SMA, Afreen F, Kozai T (2005). Temperature stress can alter the photosynthetic efficiency and secondary metabolite concentration in St. John's wort. Plant Physiol Bioch 43(1011):977-984. 